Cordova Jurnal ISNN

(P) 2302-3155

(e) $2714-5808$

Vol. 9. No. 22019
Jurnal Kajian Bahasa, dan Budaya Terbit 2 kali setahun oleh

UPT. Pusat Pengembangan Bahasa (P2B) UIN Mataram.

Tersedia Online pada

https://journal.uinmataram.ac.id/index.php/cordova

\title{
THE CORRELATION BETWEEN STUDENTS' ANXIETY AND
}

LEARNING MOTIVATION TOWARDS STUDENTS' SPEAKING

SKILL

\section{Amar Hamzah Farosy}

Faculty of language and art English department (FPBS), IKIP MATARAM marfarosy@mail.com

Dedi Sumarsono

Faculty of language and art English department (FPBS), IKIP MATARAM dedi_aqil@yahoo.com

\section{Baiq Sumarni}

Faculty of language and art English department (FPBS), IKIP MATARAM

\section{meniq100@gmail.com}

\begin{abstract}
This study aims to determine the correlation between students' anxiety and learning motivation towards students speaking skill at SMPN 19 Mataram. This research is a quantitative, counting the data used multiple correlation . The sample of this study consisted of 44 students; the instrument used in this study was an oral test and questionnaires that belongs to anxiety and motivation. Data analysis technique is multiple correlation. The findings of the study showed that the r-test was 0.618 and 0.624 . This showed that the alternative hypothesis ( $\mathrm{Ha}$ ) is accepted and as average score is high, Then the result in $\mathrm{F}$ - table shows that $\mathrm{Fh}>\mathrm{ft}(21,81375>3,22)$. From the findings of this study, it is recommended that teachers can fixed students' anxiety and teachers build the motivations students in teaching speaking skill.
\end{abstract}

Key words: students' anxiety, learning motivation, speaking skill. 
Cordova Jurnal ISNN

(P) 2302-3155

(e) $2714-5808$

Vol. 9. No. 22019
Jurnal Kajian Bahasa, dan Budaya Terbit 2 kali setahun oleh UPT. Pusat Pengembangan Bahasa (P2B) UIN Mataram. Tersedia Online pada

https://journal.uinmataram.ac.id/index.php/cordova

\section{INTRODUCTION}

Speaking is used to say that a statement describes a general feeling or opinion relating to or affecting all the people or things in a group. Speaking is one kind of tools to make it some conversation in our daily life. Speaking is used to say that a statement describes a general feeling or opinion relating to or affecting all the people or things in a group. Speaking is one kind of tools to make it some conversation in our daily life. The other four skills can be practiced alone, but for speaking, the students cannot really speak alone, that is why students should make every effort possible to find somebody to speak with (Nunan, 2000:39).

In the context of speaking English, being able to speak to friends and even speak with foreigners, in their language which both of them understand is surely the goal of many learners of English. However, the biggest problem students of English face are to speak in it. Consequently, many reasons to take into consideration might be lack of confidence in terms of anxiety about making errors (Boonkit, 2010: 22). It can be stressful when they are expected to speak in the second/foreign language before the fluency is achieved. In line with the issue of anxiety (Thornburry, 2005: 28).

Speaking is a complex skill requiring the simultaneous use of a number of defferent abilities, which often develop at the different rates. Heaton (1990: 70-71) states that there are five components are generally recognized in analyzing the speech proccess; (a) Pronounciation (including the segmental features-vowels and consonant and the stress and intonation patterns), (b) Grammar is the sounds and the sound patterns, the basic units of meaning, such as words, and the rules to combine them to form new sentences, (c) Vocabulary is single words, set phrases, variable phrases, phrasal verbs, and idiomsn, (d) fluency is the ability to talk freely without too much stopping or hesitating, (e) Comprehension is defined as the ability to understand something by a reasonable comprehension of the subject.

According to this assume, the purpose of this research is to investigate related to the students' anxiety, learning motivation and their speaking skill. The students were reluctant to speak English in the classroom and did not know how to start their speeches, when they tried to deliver their speeches; they often did not say the English words properly and used incorrect words. To solve the students' problem, in this research, the researcher tried to find out the correlation between the students' anxiety and learning motivation towards students' speaking skill. 
Cordova Jurnal ISNN

(P) 2302-3155

(e) $2714-5808$

Vol. 9. No. 22019
Jurnal Kajian Bahasa, dan Budaya Terbit 2 kali setahun oleh UPT. Pusat Pengembangan Bahasa (P2B) UIN Mataram. Tersedia Online pada

https://journal.uinmataram.ac.id/index.php/cordova

\section{REVIEW OF RELATED LITERATURE \\ The Nature of Speaking}

Speaking is an interactive process of constructing meaning that involves producing and receiving and processing information (Brown, 1994; Burns \& Joyce, 1997: 223). Its form and meaning are dependent on the context in which it occurs, including the participants themselves, their collective experiences, the physical environment, and the purposes for speaking. Nunan (2003: 48) states that speaking is a productive oral skill and it consists of producing systematic verbal utterances to convey meaning.

Based on the definitions above, it can be inferred that speaking is a basic of person skill to produce language that has meaning and be understood by other people about what the speaker says. It is a skill of speaker to give information to a listener or group of listeners by transfer it effectively and speaking activity must be set on fun situation.

\section{Motivation}

Motivation can directly affect the frequency of use of learning strategies, willingness to learn, goal setting and achievement in learning. Success and failure in language learning especially in speaking seems largely depends on student' motivation to learn English.

According to Harmer (2001: 98), Motivation is some kind of internal drive which pushes someone to do things in order to achieve something. According to Wiliams and Burden (1997) in Harmer (2001: 51) suggest that motivation is a state of cognitive arousal which provokes a decision to act, as a result of which there is sustained intellectual or physical effort so that the person can achieve some previously set goal. They go on to point out that the strength of that motivation is depend on how much value that the individual places on the outcome he or she ishes to achieve.

\section{Anxiety}

Anxiety is a negative feeling that someone having in certain time. Anxiety is a feeling where the people uncertain or hesitant with their ability or what they want to do. For the people who learn about a foreign language, anxiety may impact in their acquisition of the language. Someone with high anxiety can create a negative effect especially in foreign language class. It is because learn a foreign language we have to practice or perform the language in order to show the ability that we have. If the anxiety is had by students, it may be they will get low understand. 
Cordova Jurnal ISNN

(P) 2302-3155

(e) $2714-5808$

Vol. 9. No. 22019
Jurnal Kajian Bahasa, dan Budaya Terbit 2 kali setahun oleh UPT. Pusat Pengembangan Bahasa (P2B) UIN Mataram. Tersedia Online pada

https://journal.uinmataram.ac.id/index.php/cordova

According to Dixon (2015:5), anxiety is an essential part of human make-up. A survival instinct honed over millions of years of evolution, it involves a series of responses and reflexes that help us to avoid or deal with dangerous situations.

However for many of us something changes, our anxiety no longer sits quietly in the background waiting to spring into action should a potentially situation arise. It appears more often, more easily and seems to come to us for no reason-intangible anxiety can feel just too powerful to deal with.

\section{RESEARCH METHOD}

This research used multiple correlation two predictors design. Multiple correlation aim is to test the hypothesis contained in this study. It is a number indicating the direction and strength of the related between two independent variables together or more with one dependent variable (Sugiyono, 2017: 231).

\section{Population, Sample, and Sampling Technique}

Population is a generalization region consisting of: objects / subjects that have certain qualities and characteristics set by researchers to be studied and then drawn conclusions (Sugiyono, 2016:117). The totals of population of students are 111 students. They divide in to three classes. They are: VIII A, VIII B, VIII C. Every class consists of 30-44 students.

Sample is the group of elements, or a single element, from which data are obtained (Sugiyono, 2016: 62). Thus, the sample in this research using the random class as the sample, and the researcher was take in VIIIA with 44 students from 111 students of population.

Sampling technique is a technique of taking sample to determine the sample to be used in research (Sugiyono, 2016:118). In selecting the students as the sample, the researchers used a probability sampling method that any method of sampling that utilizes some from of random selection. From a probability sampling method the researchers used cluster random sampling technique because in the sampling, the researchers divided the population into separates groups, called cluster. Then, a simple random sample of cluster is selected from the population. The researchers conducted their analysis on data from the sampled cluster. 
Cordova Jurnal ISNN

(P) 2302-3155

(e) $2714-5808$

Vol. 9. No. 22019
Jurnal Kajian Bahasa, dan Budaya Terbit 2 kali setahun oleh UPT. Pusat Pengembangan Bahasa (P2B) UIN Mataram. Tersedia Online pada

https://journal.uinmataram.ac.id/index.php/cordova

\section{Instrument of The Research}

According Sugiyono (2016:133), the research instrument is a tool to measure the value of the variables studied. This research used questionnaire for anxiety and motivation. Then for speaking, this research used oral test by described situation as a research instrument to collecting data.

\section{Techniques of Collecting Data}

To collect the data, this research used questionnaire and speaking test.

In speaking test, the students have chance to choose provided and then described the topic choosen in front of their friends in the class room (1.Animal, 2.Flower, 3.School) and it took around 3 minutes for each student. The score of students' speaking was given to each student dealing with the scoring rubric speaking, such as pronunciation, grammar, vocabulary, fluency, and comprehension.

Questionnaire consisted of many items of statements but the researchers only took 24 items and 15 which are suitable with this study. The questionnaires are "closed", it means the respondents are only choosing the best one on the items and making checklist on the given answers. In answering the questionnaires, the students are asked to choose one of the options by giving a mark or checklist.

\section{Techniques of Data Analysis}

This research used SPSS 21 to collected and analysing the data.

a. Multiple Linier Regression.

Regression analysis is an analysis that measures the influence of the independent variables to the dependent variable.

b. Multiple Correlation

The technique of Data analysis used to find the relationship between student motivation and anxiety on speaking students is looking for the value of $\mathrm{R}$ then test $\mathrm{F}$. Multiple correlation is a relationship together between X1, X2 with Y.

c. Inferential Analysis

Inferential analysis uses statistical tests to see whether a pattern we due to chance or due to the program or intervention effects. 
Cordova Jurnal ISNN

(P) 2302-3155

(e) $2714-5808$

Vol. 9. No. 22019
Jurnal Kajian Bahasa, dan Budaya Terbit 2 kali setahun oleh UPT. Pusat Pengembangan Bahasa (P2B) UIN Mataram. Tersedia Online pada

https://journal.uinmataram.ac.id/index.php/cordova

\section{RESULT AND DISCUSSION.}

\section{Result}

a. Data Anxiety

(X1) is obtained from questionnaires containing 15 valid statements with 4 alternative answers according to rating scale (1 to $4)$, so that minimum ideal score is obtained $(1 \times 15=15)$ and maximum ideal score $(4 \times 15=60)$, so the ideal score range is 15 to 60. From the results of respondents' answers, mean score is 56.20 and standard deviation is 3.393. The mean score is almost close to maximum ideal score. Total score obtained from respondents as a whole was 2473, while total ideal score was a maximum of $(15 \mathrm{x} 4 \mathrm{x}$ $44=2640)$, than the percentage of total score is $(2473 / 2640 \times 100 \%$ $=93.67 \%)$. This number is included in excellent category. It can be seen in the histogram below:

\section{HISTOGRAM OF ANXIETY}

Histogram

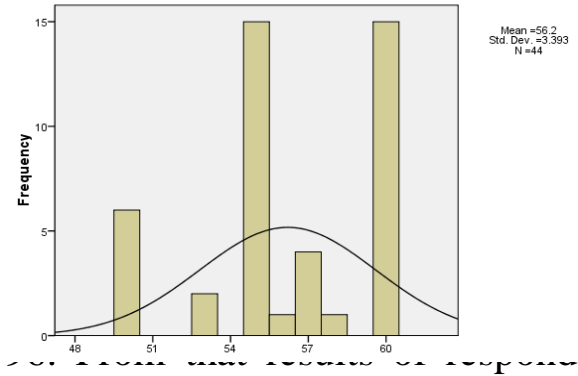

destionnaire distribution containing nswers according to the rating scale re was obtained $(1 \times 24=24)$ and ), so ranking of ideal score is 24 to 82.11 and a standard deviation of 7.121. Total score obtained from all total score is 3613 , while maximum total ideal score is $(24 \times 4 \times 44=$ $4224)$, so percentage of all total score is $(3613 / 4224 \times 100 \%=$ $85.53 \%)$. This number is included in the excellent category. It can be seen in the histogram below: 
Cordova Jurnal ISNN

(P) 2302-3155

(e) $2714-5808$

Vol. 9. No. 22019
Jurnal Kajian Bahasa, dan Budaya Terbit 2 kali setahun oleh UPT. Pusat Pengembangan Bahasa (P2B) UIN Mataram. Tersedia Online pada

https://journal.uinmataram.ac.id/index.php/cordova

\section{HISTOGRAM OF MOTIVATION}

Histogram

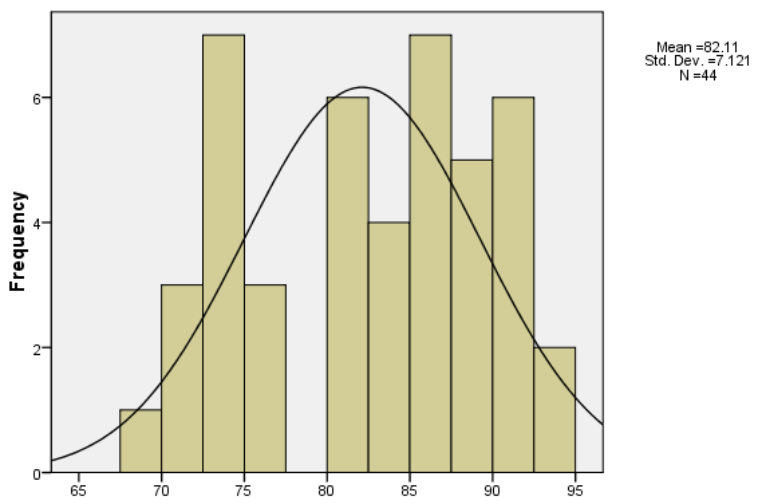

c. Data Speaking

(Y) was obtained from the oral test by describing the topic of pictures given (1. Animal, 2. Flower, 3. School) and it was taking around 3 minutes for each student. The score of students' speaking was given to each student dealing with the scoring rubric speaking, such as pronunciation, grammar, vocabulary, fluency, and comprehension, than obtained minimal ideal score $(1 \times 16=16)$ and maximum ideal score $(4 \times 16=64)$, so ideal score range is 16 to 64 . From the results of the respondents' answers mean score is 53.91 and the standard deviation is 5.317. Total score obtained from respondents as a whole was 2372 , while maximum ideal score $(16 \times 4$ x $44=2816)$, so the percentage of total score totaled $(2372 / 2816 x$ $100 \%=84.23 \%)$. This number is included in the excellent category. It can be seen in the histogram below:

\section{HISTOGRAM OF SPEAKING}

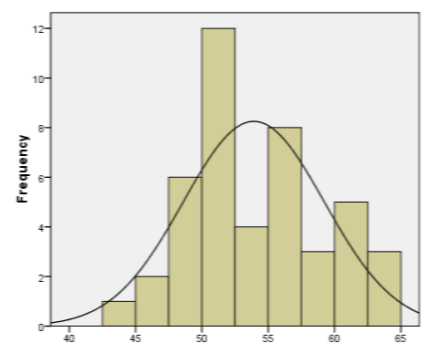


Cordova Jurnal ISNN

(P) 2302-3155

(e) $2714-5808$

Vol. 9. No. 22019
Jurnal Kajian Bahasa, dan Budaya Terbit 2 kali setahun oleh UPT. Pusat Pengembangan Bahasa (P2B) UIN Mataram. Tersedia Online pada

https://journal.uinmataram.ac.id/index.php/cordova

\section{Discussion.}

Research questions have been answered based on the results of research above . After calculation is done, it can be seen that fvalue> ftable or $21.81375>3.22$ in degrees of freedom of 41 students $(44-2-1=41)$. Thus the researcher concluded that $\mathrm{Ha}$ stated "There is a correlation of students 'anxiety and learning motivation towards students' speaking skills" is accepted. While Ho which stated "There is no correlation of students 'anxiety and learning motivation towards students' speaking skills" is rejected. In other words, there is a significant correlation between anxiety (X1) and motivation (X2) towards speaking skill (Y).

Speaking skills are the main tool of communication, and then students can interact with their friends. There are several factors that influence students' speaking skills, one of which is anxiety. This anxiety is strength or will and can also be a deficiency that has an effect on students during a conversation or discussion. Willingness is made when students clearly understand what needs to be done and why. in relation to that, According to Kirkwood and Melton (2002: 65), anxiety disorders are among the most common mental disorders encountered by public speakers. People who feel anxiety while speaking in public generally tend to avoid situations where they have to perform, but when they encounter such situations, they suffer intense distress and anxiety. According to them, that a weak mentality will tend to be a feeling that makes us afraid of all situations, so here it is comfort to talk with a situation that is not accompanied by pressure that will make students ready to make a communication.

Another factor effecting students speaking skill is motivation. Motivation also as important factor which support the students in learning especially for develop their speaking skill. However students have less motivation they will not interest to speak English. it is easy in language learning to claim that a learner will be more successful with the proper motivation.

Motivation is the reason for someone to do something, and when students have motivation, the students will be more active in learning and teaching process and the aim of learning can be achieve. in relation to that Harmer (2001) suggested that motivation is some kind of internal drive which pushes someone to do things in order to achieve the goal such as goal setting, learning environment and interesting class. In addition, motivation is all power that pushes someone to do something (Nasution, 2000).

Itu can be concluded that anxiety and motivation have a significant correlation in speaking. First, it is because of anxiety is unreal feelings, it can 
Cordova Jurnal ISNN

(P) 2302-3155

(e) $2714-5808$

Vol. 9. No. 22019
Jurnal Kajian Bahasa, dan Budaya Terbit 2 kali setahun oleh UPT. Pusat Pengembangan Bahasa (P2B) UIN Mataram. Tersedia Online pada

https://journal.uinmataram.ac.id/index.php/cordova

be support by great motivation than they can have a comfort situation to make some communication. Second, anxiety is some fear feeling that usually when they want something or doing something but they afraid to make it clear, than looking somebody or someone who can doing that what they want, that's can be great motivation for them for doing something especially in speaking.

\section{CONCLUSION AND SUGGESTION}

\section{Conclusion}

Based on the result of this research, it could be concluded as follows:

There was any correlation between students' anxiety and speaking at second grade of SMPN 19 Mataram r-test $0.618>$ r-table 0.304. It means that students' anxiety followed higher or lowest inters level of students.

\section{Suggestions}

From the conclusion above, some suggestion are offered for the students and teacher as follows:

1. For teacher

a. Teacher should give motivation for students in speaking. So the students never feelings anxiety in speaking

b. Teacher should fix the lack of anxiety in speaking. So can make student active in process learning especially in speaking.

c. Teacher should give more attention for students' psychology to build anxiety and motivation in speaking

2. For students

For students, students are expected to develop theirs anxiety and motivation in speaking begins with the reading they enjoy. So the students will be easier to be active in process learning and can be a good habit for their future

This study is expected to provide useful information about the teaching and learning English, especially in students' speaking skill related to their anxiety and how to learn motivation. This study is also useful for teacher, students, and the other researcher which described in the following points:

- Teacher: the result of this study will be used in teachinglearning proccess. Expected very useful for all English teacher in teaching speaking skill. 
Cordova Jurnal ISNN

(P) 2302-3155

(e) 2714-5808

Vol. 9. No. 22019
Jurnal Kajian Bahasa, dan Budaya Terbit 2 kali setahun oleh UPT. Pusat Pengembangan Bahasa (P2B) UIN Mataram. Tersedia Online pada

https://journal.uinmataram.ac.id/index.php/cordova

- Student: it assists them to solve their problem in speaking activity and it can help them to improve their speaking skill, especially for solve their anxiety and tell them about how to learn motivation.

- School: the result of this will be expected to be additional references for the school as well. 
Cordova Jurnal ISNN

(P) 2302-3155

(e) $2714-5808$

Vol. 9. No. 22019
Jurnal Kajian Bahasa, dan Budaya Terbit 2 kali setahun oleh UPT. Pusat Pengembangan Bahasa (P2B) UIN Mataram. Tersedia Online pada

https://journal.uinmataram.ac.id/index.php/cordova

\section{REFERENCES}

Antonio and Diclemente, Carlo C. 2015.More Than Anxiety: A Transtheoretical Approach. the United States of America.

Brown. 2001. Teaching by Principles An Interactive Approach to Language Pedagogy. USA: Longman.

H.D. 2004. Language assessment principles and classroom practices New York :pearson Education, Inc, 2007. Principles of language learning and teaching, fifth edition. Pearson education, 10 bank street, white plains, NY 10606

Dixon, Terry. 2015. Anxiety Understanding Problems. Published by HelpFor www.help-for.com.

Dornyei Zoltan. 2001. Motivation in second foreign language learnig. Cambridge journals

Hughes, A. 2003.Testing for Language Teachers. United Kingdem: Cambrige

Keller, J. M. (2009).Motivational design for learning performance: The ARCS model approach. Springer science \& Business media.

Keller, jhon M. " Development and use of the ARCS model of instructional design. " journal of instructional development 10, no 3 (1987):210 .

Kothari, C.R. 2004. Research methodology. New Delhi: New Age International Publisher

Abdul waris, 2018, the correlation between students' motivation and anxiety towards speaking skill. Unpublished thesis.

Sugiyono. 2017. .StatistikaUntukPenelitian. Alpabeta : Bandung 2016. Metodepenelitianpendidikan. Alpabeta : Bandung.

SyaifulbahriDjamarah. 2011. Pisikologibelajar. RinekaCipta : Jakarta.

SS 